\title{
Effect Threshold for Selenium Toxicity in Juvenile Splittail, Pogonichthys macrolepidotus A
}

\author{
Mark C. Rigby • Xin Deng • Thomas M. Grieb • \\ Swee J. Teh $\cdot$ Silas S. O. Hung
}

Received: 5 April 2009/Accepted: 18 September 2009/Published online: 1 October 2009

(c) The Author(s) 2009. This article is published with open access at Springerlink.com

\begin{abstract}
In fish, selenium can bioaccumulate and cause adverse impacts. One of the fish species potentially at risk from selenium in the San Francisco Bay (California, USA) is the splittail (Pogonichthys macrolepidotus). Previous studies have derived a whole body NOAEL and LOAEL of 9.0 and $12.9 \mathrm{mg} / \mathrm{kg}-\mathrm{dw}$, respectively, for selenium in juveniles. However, the NOAEL/LOAEL approach leaves some uncertainty regarding the threshold of toxicity.
\end{abstract}

M. C. Rigby ( $\square)$

Parsons, 406 West South Jordan Parkway Suite 300,

South Jordan, Utah 84095, USA

e-mail: mark.rigby@parsons.com; rigby16@comcast.net

M. C. Rigby

Marine Science Institute, University of California,

Santa Barbara, CA 93106-6150, USA

M. C. Rigby - T. M. Grieb

Tetra Tech, 3746 Mt. Diablo Blvd. Suite 300, Lafayette, CA 94549, USA

X. Deng

Aquatic Toxicology Program, Department of Anatomy, Physiology, and Cell Biology, School of Veterinary Medicine, University of California, Davis, CA 95616, USA

Present Address:

X. Deng

Department of Pesticide Regulation, 1001 I Street, Sacramento, CA 95812-4015, USA

\section{S. J. Teh}

Aquatic Toxicology Program, Department of Anatomy, Physiology, and Cell Biology, School of Veterinary Medicine, University of California, Davis, CA 95616, USA

\section{S. S. O. Hung}

Department of Animal Science, University of California, Davis, CA 95616, USA
Therefore, the raw data from the original experiment was re-analyzed using a logistic regression to derive $\mathrm{EC}_{10}$ values of $0.9 \mathrm{mg} / \mathrm{kg}$-dw in feed, $7.9 \mathrm{mg} / \mathrm{kg}$ - $\mathrm{dw}$ in muscle, $18.6 \mathrm{mg} / \mathrm{kg}-\mathrm{dw}$ in liver for juvenile splittail. Selenium concentrations in the dietary items of wild splittail exceed the $\mathrm{EC}_{10}$ values derived here. Thus, deformities previously reported in wild splittail may have resulted from selenium exposures via the food chain.

Keywords Selenium $\cdot \mathrm{EC}_{10} \cdot$ Splittail $\cdot$ Deformities

Selenium can bioaccumulate in aquatic organisms resulting in adverse effects when it exceeds threshold levels. In fish, these effects can include reduced production of viable eggs, post-hatch mortality, deformities in growing stages, and various pathological effects in the kidneys, liver, heart, and ovaries (Hamilton 2003, 2004; Lemly 2002). In severe cases, these effects may lead to population declines (Lemly 2002).

The San Francisco Bay (California, USA) receives inputs of selenium from several sources. The most important selenium loads are the Sacramento River (i.e., the dominant freshwater inflow to the bay during the wet season), agricultural drainage (via the San Joaquin River), local tributaries, and effluent from oil refineries, municipal wastewater treatment facilities, and other industrial facilities (Presser and Luoma 2006). Since there are several threatened and endangered fish species in the San Francisco Bay (Beckon and Maurer 2007), the potential for adverse impacts to those fish from selenium has generated substantial concern (Beckon and Maurer 2007; San Francisco Bay Regional Water Quality Control Board 2007). Additionally, the North San Francisco Bay has been identified as being impaired for selenium under Sect. 303(d) of 
the Clean Water Act, and a total maximum daily load (TMDL) for selenium is under development (San Francisco Bay Regional Water Quality Control Board 2007).

Splittail (Pogonichthys macrolepidotus), a cyprinid native to the San Francisco Estuary, was listed as a threatened species between 1999 and 2003, and continues to be a species of special concern in the California Department of Fish and Game (Sommer et al. 2007). To examine the potential adverse impacts of selenium on splittail, Teh et al. (2004) fed juvenile splittail organic selenium for 9 months in the laboratory. From this experiment, Teh et al. (2004) derived a no observed adverse effects level (NOAEL) and lowest observed adverse effects level (LOAEL) for deformities in juvenile splittail of 10.1 and $15.1 \mathrm{mg} / \mathrm{kg}$-dry weight (dw) in muscle tissue and 23.0 and $26.8 \mathrm{mg} / \mathrm{kg}$-dw in liver tissue, respectively. When converted to whole body concentrations using the equations from U.S. Environmental Protection Agency (2004), the NOAEL and LOAEL are 9.0 and $12.9 \mathrm{mg} / \mathrm{kg}-\mathrm{dw}$, respectively. These values are higher than the proposed aquatic life water quality criterion (ALWQC) of $7.9 \mathrm{mg} / \mathrm{kg}$-dw in fish tissue.

To determine the NOAEL and LOAEL, Teh et al. (2004) analyzed their data using an analysis of variance (ANOVA). However, this type of analysis leaves some uncertainty as to where the toxicity threshold lies between the NOAEL and LOAEL, or if it is even below the NOAEL. Therefore, it is uncertain whether the threshold for selenium toxicity in splittail is above or below the proposed ALWQC. To derive a more precise estimate of the threshold for selenium toxicity in splittail, the raw data from Teh et al. (2004) was reanalyzed using a logistic regression.

\section{Materials and Methods}

Fish were maintained as described in Teh et al. (2004). Briefly, 7-month-old juvenile splittail (6.8 g average) were placed in 24 indoor flow-through $(4 \mathrm{~L} / \mathrm{min})$ tanks $(90 \mathrm{~L}$ each, $66 \mathrm{~cm}$ in diameter), with 40 fish randomly assigned to each tank. Water temperature was maintained at $23^{\circ} \mathrm{C}$ during the first 6 months of exposure but dropped to $18^{\circ} \mathrm{C}$ for the rest of the experiment.

The basal diet was described in detail in Teh et al. (2004). Torula and selenized yeast were added to the feed to create eight diets with the following selenium concentrations: 0.4 (no selenized yeast), 0.7, 1.4, 2.7, 6.6, 12.6, 26.0, and 57.6 (no Torula yeast) $\mathrm{mg} / \mathrm{kg}-\mathrm{dw}$. Fish were fed twice daily (9:00 a.m. and 4:00 p.m.) with a daily feeding rate of $3 \%$ body weight (BW) in the first 5 months and adjusted to $2 \% \mathrm{BW} /$ day for the remaining 4 months of the experiment. Each diet was randomly assigned to three tanks.
At the end of 9 months, five fish from each tank were randomly collected and sampled. The following data were collected for each fish: presence of deformities (yes/no), total length, body weight, and the concentrations of selenium in muscle and liver tissue. From these measurements, condition factor (i.e., CF, i.e., $100 \times$ body weight $(\mathrm{g}) /$ [body length $(\mathrm{cm})]^{3}$ ) was calculated.

To determine if there was a relationship between the presence of deformities and the concentration of selenium in the feed, muscle, and liver, the data was analyzed using a logistic regression with maximization of Firth's penalized likelihood function using the Newton-Raphson algorithm in XLSTAT 2008. The logistic regression is the most appropriate type of regression to use to analyze this type of data as the response is binary; i.e., animals were classified as either normal or deformed. The concentration data was logarithm (base 10) transformed prior to analysis.

\section{Results and Discussion}

As shown in Table 1, the concentration of selenium in muscle and liver tissue increased with the concentration of dietary selenium. The prevalence of deformities also increased with the concentration of dietary selenium from 0.4 to $6.6 \mathrm{mg} / \mathrm{kg}-\mathrm{dw}$. At concentrations greater than $6.6 \mathrm{mg} / \mathrm{kg}-\mathrm{dw}$, the prevalence of deformities decreased (Table 1). However, body weight, total length, and condition factor significantly decreased at concentrations of $26.0 \mathrm{mg} / \mathrm{kg}-\mathrm{dw}$ and greater (Table 1; Teh et al. 2004).

Since the purpose of this analysis was to find the lowest concentration at which adverse effects occurred, only the prevalence of deformities in fish fed selenium at 0.4 $6.6 \mathrm{mg} / \mathrm{kg}-\mathrm{dw}$ were used in the re-analysis. At concentrations greater than $12.6 \mathrm{mg} / \mathrm{kg}-\mathrm{dw}$, body weight, total length, and condition factor decreased, with significant decreases at dietary selenium concentrations of $26 \mathrm{mg} / \mathrm{kg}$ $\mathrm{dw}$ and greater (Table 1).

The probability of deformities increased with the concentration of selenium in feed (logistic regression, -2log $($ likelihood $)=60.41, \quad r^{2} \quad($ Nagelkerke $)=0.32, \quad$ Akike's Information Criterion (AIC) $=66.41, \mathrm{df}=73, p=0.002$ ), muscle (logistic regression, $-2 \log ($ likelihood $)=56.12, r^{2}$ $($ Nagelkerke $)=0.39, \mathrm{AIC}=62.12, \mathrm{df}=73, p=0.0004)$, and liver (logistic regression, $-2 \log \left(\right.$ likelihood) $=55.00, r^{2}$ $($ Nagelkerke $)=0.31$, AIC $=61.00, \mathrm{df}=69, p=0.005)$. The equations for the probability of deformities from the best fitting logistic regression models are as follows:

\section{1}

$\overline{1+\mathrm{e}^{-\left(-2.02+2.47 \times \log _{10}(\text { Se in feed })\right)}}$ 
Table 1 Mean concentrations of selenium in feed, muscle, and liver versus the mean prevalence of deformities, weight, total length, and condition factor $(\mathrm{CF})$ in juvenile splittail

\begin{tabular}{|c|c|c|c|c|c|c|c|}
\hline \multicolumn{3}{|c|}{ Selenium $(\mathrm{mg} / \mathrm{kg}-\mathrm{dw})$ in } & \multirow[t]{2}{*}{ Deformities $^{2}(\%)$} & \multirow[t]{2}{*}{ Weight $^{1}$ BW (g) } & \multirow[t]{2}{*}{ Total length $^{1}(\mathrm{~cm})$} & \multirow[t]{2}{*}{$\mathrm{CF}^{1}$ (unitless) } & \\
\hline Feed & Muscle $^{1}$ & Liver $^{1}$ & & & & & \\
\hline 0.4 & $6.7^{\mathrm{a}}$ & $20.0^{\mathrm{a}}$ & $0^{\mathrm{a}}$ & $34.2^{\mathrm{a}}$ & $15.7^{\mathrm{ab}}$ & $0.81^{\mathrm{a}}$ & \\
\hline 0.7 & $6.9^{\mathrm{ab}}$ & $18.6^{\mathrm{a}}$ & $6.7^{\mathrm{a}}$ & $34.0^{\mathrm{a}}$ & $15.7^{\mathrm{ab}}$ & $0.83^{\mathrm{a}}$ & \\
\hline 1.4 & $9.1^{\mathrm{bc}}$ & $20.0^{\mathrm{a}}$ & $26.7^{\mathrm{a}, \mathrm{b}}$ & $30.5^{\mathrm{a}}$ & $15.6^{\mathrm{ab}}$ & $0.77^{\mathrm{ab}}$ & \\
\hline 2.7 & $10.1^{\mathrm{c}}$ & $23.0^{\mathrm{a}}$ & $20.0^{\mathrm{a}, \mathrm{b}}$ & $29.5^{\mathrm{a}}$ & $15.1^{\mathrm{ab}}$ & $0.81^{\mathrm{a}}$ & NOAEL \\
\hline 6.6 & $15.1^{\mathrm{d}}$ & $27.0^{\mathrm{b}}$ & $53.3^{\mathrm{b}}$ & $32.9^{\mathrm{a}}$ & $15.6^{\mathrm{ab}}$ & $0.78^{\mathrm{ab}}$ & LOAEL \\
\hline 12.6 & $18.9^{\mathrm{e}}$ & $31.3^{\mathrm{b}}$ & $26.7^{\mathrm{a}, \mathrm{b}}$ & $40.0^{\mathrm{a}}$ & $16.2^{\mathrm{a}}$ & $0.81^{\mathrm{a}}$ & \\
\hline 26.0 & $29.4^{\mathrm{f}}$ & $40.9^{\mathrm{b}}$ & $6.7^{\mathrm{a}}$ & $19.1^{\mathrm{b}}$ & $13.6^{\mathrm{b}}$ & $0.71^{\mathrm{b}}$ & \\
\hline 57.6 & $38.5^{\mathrm{g}}$ & $86.8^{\mathrm{c}}$ & $0^{\mathrm{a}}$ & $7.9^{\mathrm{c}}$ & $10.9^{\mathrm{c}}$ & $0.6^{\mathrm{c}}$ & \\
\hline
\end{tabular}

${ }^{1}$ Means with different superscripts are significantly different, as reported by Teh et al. (2004)

${ }^{2}$ Means with different superscripts are significantly different, as determined using Fisher's exact test $B W$ Body weight, $C F$ condition factor

$$
\begin{aligned}
& \frac{1}{1+\mathrm{e}^{-\left(-10.13+8.84 \times \log _{10}(\text { Se in muscle })\right)}} \\
& \frac{1}{1+\mathrm{e}^{-\left(-16.09+10.95 \times \log _{10}(\text { Se in liver })\right)}}
\end{aligned}
$$

Using these equations, $1,5,10$, and $20 \%$ effect concentrations were calculated for selenium in feed, muscle, and liver from the data produced by Teh et al. (2004) (Table 2). The $\mathrm{EC}_{10}$ values predicted using the logistic regression were below both the NOAEL and LOAEL determined by Teh et al. (2004) of 2.7 and $6.6 \mathrm{mg} / \mathrm{kg}-\mathrm{dw}$ in feed; 10.1 and $15.1 \mathrm{mg} / \mathrm{kg}-\mathrm{dw}$ in muscle; and 23.0 and $27.0 \mathrm{mg} / \mathrm{kg}-\mathrm{dw}$ in liver, respectively.

In the calculation of the $\mathrm{EC}_{10}$, the three highest dietary selenium concentrations (i.e., 12.6, 26.0 and $57.6 \mathrm{mg} / \mathrm{kg}$ $\mathrm{dw}$ ) were excluded. In these three concentrations, the prevalence of deformities steadily decreased (Table 1) from the highest prevalence of deformities that was observed at $6.6 \mathrm{mg} / \mathrm{kg}$-dw. At the two highest concentrations, body weight, total length, and condition factor also significantly decreased (Table 1). Since the only adverse effect that was observed at the lower doses was deformities, the $\mathrm{EC}_{10}$ for deformities is protective of the other adverse effects observed in the experiment from exposures to dietary selenium; i.e., reduced body weight, total length, and condition factor. Further, since logistic regressions can only be used to examine straight line relationships, the highest three doses were excluded as the third to the highest dose represented an inflection point up to which the prevalence of deformities increased and after which it decreased.

The diet of splittail consists of bivalves (including Corbicula fluminea and Potamocorbula amurensis), amphipods, cladocerans, harpacticoid copepods, mysids, and detritus (Moyle et al. 2004). In the San Francisco Bay, selenium concentrations in amphipods and mysids range from 1 to $3 \mathrm{mg} / \mathrm{kg}$-dw (Stewart et al. 2004) and in the clams $C$. fluminea and $P$. amurensis selenium concentrations range from 2 to 9 and 5 to $20 \mathrm{mg} / \mathrm{kg}$-dw, respectively (Stewart et al. 2004; Presser and Luoma 2006). These concentrations exceed the dietary $\mathrm{EC}_{10}$ of $0.9 \mathrm{mg} / \mathrm{kg}-\mathrm{dw}$ (Table 2). Greenfield et al. (2008) reported mean selenium concentrations in the livers of adult splittail from three locations in the San Francisco Bay caught in 2001 and 2002. The average concentrations ranged from $8.36 \pm$ standard deviation of 0.66 to $16.30 \pm 1.83 \mathrm{mg} / \mathrm{kg}$ $\mathrm{dw}$. While the mean concentrations are all below the $\mathrm{EC}_{10}$

\begin{tabular}{|c|c|c|c|c|c|c|c|c|c|}
\hline \multirow[t]{2}{*}{$\mathrm{EC}_{\mathrm{x}}(\%)$} & \multicolumn{3}{|c|}{ Feed (mg/kg-dw) } & \multicolumn{3}{|c|}{ Muscle (mg/kg-dw) } & \multicolumn{3}{|c|}{ Liver (mg/kg-dw) } \\
\hline & Mean & $\mathrm{UCL}_{95}$ & $\mathrm{LCL}_{95}$ & Mean & $\mathrm{UCL}_{95}$ & $\mathrm{LCL}_{95}$ & Mean & $\mathrm{UCL}_{95}$ & $\mathrm{LCL}_{95}$ \\
\hline 1 & 0.09 & 0.0003 & 0.36 & 4.23 & 1.29 & 6.07 & 11.22 & 2.05 & 15.30 \\
\hline 5 & 0.42 & 0.02 & 0.97 & 6.50 & 3.30 & 8.16 & 15.88 & 6.52 & 19.06 \\
\hline 10 & 0.85 & 0.10 & 1.60 & 7.90 & 4.99 & 9.45 & 18.59 & 10.84 & 21.38 \\
\hline 20 & 1.81 & 0.64 & 3.22 & 9.75 & 7.52 & 11.50 & 22.04 & 17.61 & 25.87 \\
\hline
\end{tabular}
of $18.6 \mathrm{mg} / \mathrm{kg}$-dw for livers, the $95 \mathrm{th}$ percentile for the

Table 2 Predicted effect concentrations (ECs) and confidence intervals

$U C L_{95} 95 \%$ Upper confidence limit, $L C L_{95} 95 \%$ lower confidence limit 
location with the highest mean concentration is approximately $19.9 \mathrm{mg} / \mathrm{kg}$-dw (calculated as mean +1.96 standard deviations). However, it should be noted that in the following year, the mean concentration at this location decreased to $8.84 \pm 0.76 \mathrm{mg} / \mathrm{kg}-\mathrm{dw}$ and that the $\mathrm{EC}_{10}$ derived here is for juveniles. Nonetheless, given that selenium concentrations in the dietary items of splittail exceed the $\mathrm{EC}_{10}$ for deformities, deformities may be expected in wild splittail, as has been reported by Stewart et al. (2004).

The NOAEL and LOAEL for deformities in juvenile splittail (Teh et al. 2004) are moderately higher than the U.S. Environmental Protection Agency (2004) proposed ALWQC of $7.91 \mathrm{mg} / \mathrm{kg}$-dw (whole body). Converting the NOAEL, LOAEL, and $\mathrm{EC}_{10}$ calculated here of 10.1, 15.1, and $7.90 \mathrm{mg} / \mathrm{kg}-\mathrm{dw}$ (in muscle), respectively, to an equivalent whole body concentration using the equation from U.S. Environmental Protection Agency (2004) yields values of $9.0,12.9$, and $7.2 \mathrm{mg} / \mathrm{kg}-\mathrm{dw}$ (whole body), respectively. While the NOAEL and LOAEL are greater than U.S. Environmental Protection Agency (2004) proposed ALWQC of $7.9 \mathrm{mg} / \mathrm{kg}$-dw, the $\mathrm{EC}_{10}$ is within the range of analytical error of the proposed ALWQC. However, it should be noted that the equation used to convert muscle concentrations to a whole body concentration was developed from data collected from bluegill. Therefore, the result calculated from the equation may not be accurate for other fish species (e.g., splittail).

The proposed ALWQC was based on a study conducted by Lemly (1993) using bluegill (Lepomis macrochirus). In a recent study designed to replicate Lemly's (1993) experiment, McIntyre et al. (2008) exposed juvenile bluegill to three different combinations of selenium species and temperature. The calculated $\mathrm{EC}_{10}$ values from the study ranged from 9.6 to $13.3 \mathrm{mg} / \mathrm{kg}-\mathrm{dw}$ (whole body). These results are all greater than the proposed ALWQC and the $\mathrm{EC}_{10}$ for splittail. Additionally, the results of McIntyre et al. (2008) indicate that differences in the experimental temperature regimes and selenium speciation can affect the toxicity of selenium and imply that further investigation of the effect of these factors on splittail may be warranted.

Acknowledgements This work was conducted in association with the North San Francisco Bay Selenium TMDL under preparation by the California Regional Water Quality Control Board, San Francisco Bay Region, with funding for the Regional Board project from the Western States Petroleum Association. We would also like to thank
Ryan Hechinger, Armand Kuris, Kevin Lafferty, Diran Tashjian, and Tetra Tech, Inc. for their support.

Open Access This article is distributed under the terms of the Creative Commons Attribution Noncommercial License which permits any noncommercial use, distribution, and reproduction in any medium, provided the original author(s) and source are credited.

\section{References}

Beckon WN, Maurer TC (2007) Species at risk from selenium exposure in the San Francisco estuary. U.S. Fish and Wildlife Service, Sacramento, California

Greenfield BK, Teh SJ, Ross JRM, Hunt J, Zhang GH, Davis JA, Ichikawa G, Crane D, Hung SSO, Deng DF, Teh FC, Green PG (2008) Contaminant concentrations and histopathological effects in Sacramento splittail (Pogonichthys macrolepidotus). Arch Environ Contam Toxicol 55:270-281

Hamilton SJ (2003) Review of residue-based selenium toxicity thresholds for freshwater fish. Ecotoxicol Environ Saf 56:201210

Hamilton SJ (2004) Review of selenium toxicity in the aquatic food chain. Sci Total Environ 326:1-31

Lemly AD (1993) Metabolic stress during winter increases the toxicity of selenium to fish. Aquat Toxicol 27:133-158

Lemly AD (2002) Symptoms and implications of selenium toxicity in fish: The Belews Lake case example. Aquat Toxicol 57:39-49

McIntyre DO, Pacheco MA, Garton MW, Wallschläger D, Delos CG (2008) Effect of selenium on juvenile bluegill sunfish at reduced temperature. EPA-822-R-08-020. 9. U.S. Environmental Protection Agency, Washington, DC

Moyle PB, Baxter RD, Sommer T, Foin TC, Matern SA (2004) Biology and population dynamics of Sacramento splittail (Pogonichthys macrolepidotus) in the San Francisco Estuary: a review. San Francisco Estuary \& Watershed Science 2:1-47

Presser TS, Luoma SN (2006) Forecasting selenium discharges to the San Francisco Bay-Delta estuary: ecological effects of a proposed San Luis drain extension. USGS Professional Paper 1646

San Francisco Bay Regional Water Quality Control Board (2007) Project plan-north San Francisco Bay selenium TMDL

Sommer TR, Baxter RD, Feyrer F (2007) Splittail "delisting": a review of recent population trends and restoration activities. Am Fish Soc Symp 53:25-38

Stewart RA, Luoma SN, Schlekat CE, Doblin MA, Hieb KA (2004) Food web pathway determines how selenium affects aquatic ecosystems: a San Francisco Bay case study. Environ Sci Technol 38:4519-4526

Teh SJ, Deng X, Deng DF, Teh FC, Hung SSO, Fan TWM, Liu J, Higashi RM (2004) Chronic effects of dietary selenium on juvenile Sacramento splittail (Pogonichthys macrolepidotus). Environ Sci Technol 38:6085-6093

U.S. Environmental Protection Agency (2004) Draft aquatic life water quality criteria for selenium 2004. EPA-822-D-04-001. Office of Water, Washington, DC 